\title{
Is Split-Night Polysomnography Valid for Women with Obstructive Sleep Apnea?
}

\author{
Mi-Ri Kang, Ki-Hwan Ji \\ Department of Neurology, Busan Paik Hospital, Inje University College of Medicine, Busan, Korea \\ 분할수면다원검사는 여성 폐쇄수면무호흡 환자에게 유효한가? \\ 강미리, 지기환 \\ 인제대학교 의과대학 부산백병원 신경과학교실
}

Received November 4, 2020

Revised November 24, 2020

Accepted November 25, 2020

Address for correspondence

Ki-Hwan Ji, MD

Department of Neurology,

Busan Paik Hospital,

Inje University

College of Medicine,

75 Bokji-ro, Busanjin-gu,

Busan 47392, Korea

Tel: $+82-51-890-8613$

Fax: +82-51-890-6367

E-mail: kihwanji@gmail.com
Objectives: Split-night polysomnography (PSG) can be used for the diagnosis and treatment of obstructive sleep apnea (OSA). Recently, the American Academy of Sleep Medicine has broadened the indication of split-night PSG from severe to moderate OSA in a time window of 2 hours. However, majority pieces of evidence have been derived from the male predominant study population. The objective of this study was to investigate the diagnostic accuracy of split-night PSG in Korean women. Methods: This study included 122 adult women with OSA. Apnea-hypopnea index (AHI) from the first 120 minutes of clock time (T120AHI) and full-night AHI (FN-AHI) were compared using the concordance correlation coefficient (CCC) method and Bland-Altman plot. Receiver operating characteristic (ROC) curves and the area under the ROC curves were plotted with various cut-off points of AHI. Results: The T120-AHI correlated with FNAHI (CCC $=0.77$ ). The area under the ROC curve for T120-AHI with FN-AHI $\geq 15$ was 0.865 , with a sensitivity of $78.6 \%$ and specificity of $82.7 \%$. Conclusions: T120-AHI showed a significant correlation with the FN-AHI value in Korean female patients with OSA.

J Sleep Med 2020;17(2):148-153

Key Words: Split-night polysomnography, Polysomnography, Woman, Obstructive sleep apnea, Daignosis.

\section{서 론}

폐쇄수면무호흡은 수면 중 반복적인 상기도의 폐색으로 인해 호흡의 저하나 중단을 야기하며 저산소증이나 각성을 유발한다. ${ }^{1}$ 또한, 주간졸림증을 촉발하고 인지기능 저하, 고 혈압을 비롯한 심뇌혈관계 질병 및 대사성 질환의 위험인자 이다. ${ }^{2}$ 폐쇄수면무호흡을 진단하는 표준방법인 수면다원검 사(polysomnography, PSG)는 최근 국내에서 급여화가 시행 되어 환자가 부담하는 검사비용 저하로 인해 검사 접근도는 높아졌으나, 검사자원의 한정으로 인해 여전히 검사시행까 지의 긴 대기기간이 존재한다. 무호흡의 치료로 양압 환기 (continuous positive airway pressure, CPAP) 치료를 선택

This is an Open Access article distributed under the terms of the Creative Commons Attribution Non-Commercial License (https://creativecommons.org/licenses/by-nc/4.0) which permits unrestricted non-commercial use, distribution, and reproduction in any medium, provided the original work is properly cited.
하면 자동양압기를 사용하지 않는 한, 원칙적으로 양압 적정 (CPAP titration)을 위한 추가적인 PSG가 필요하다. 국내보 다 먼저 PSG가 일찍 대중화된 서구선진국에서도 검사 비용, 접근성, 검사 소요 시간 등의 측면이 진단 및 치료의 잠재적 인 저해요소로 작용했던 바, 하룻밤의 PSG에서 진단과 치료 를 동시에 하는 분할수면다원검사(split-night PSG)의 사용 을 권장하고 있다. ${ }^{3,4}$ 초기 미국수면학회에서는 최소 2시간 동안 PSG 검사에서 무호흡-저호흡지수(apnea-hypopnea index, $\mathrm{AHI}$ )가 시간당 40회 이상의 환자 또는 $\mathrm{AHI}$ 가 20회 이상이면서 양압치료가 필요하다고 판단되는 경우, 수면 후 반기에 양압 적정을 시행할 수 있다고 하였으나, 최근에는 $\mathrm{AHI}$ 가 15 회 이상인 경우로 그 적용 범위를 넓힌 바 있다. 4,5 하지만 이 근거는 주로 서구에서 진행된 연구에 기반을 두 어 동양인을 대상으로 한 연구결과는 부족한 현실이다. ${ }^{6-9}$ 한 국인을 대상으로 한 연구에서는 수면다원검사 시작 후 2시 
간 동안의 $\mathrm{AHI}$ 와 전체 $\mathrm{AHI}$ 의 일치율이 높다는 결과를 보 였다. 하지만 이 연구는 전체 대상 150 명 중 남성이 123 명으 로 남성의 비율(82\%)이 여성에 비해 월등히 높았고, 따로 여 성 집단에서만 $\mathrm{AHI}$ 의 일치도를 비교한 결과는 없었다..$^{10}$ 여 성이 동일한 체질량지수의 남성보다 폐쇄수면무호흡의 중 증도가 덜하며, NREM수면에 비해 REM수면 중 폐쇄수면 무호흡이 더 심하다는 것을 고려하면, 남성중심의 연구에서 도출한 결과를 여성에게 그대로 적용하는 것이 무리일 수 있다. ${ }^{11-13}$ 본 연구는 폐쇄수면무호흡 진단을 위해 PSG를 시 행한 여성만을 대상으로 2시간 동안의 $\mathrm{AHI}$ 와 전체 $\mathrm{AHI}$ 의 일치도를 확인하고자 하였다.

\section{방 법}

본 연구는 부산 지역의 한 대학병원 수면클리닉에서 2011 년 11월 2019년 6월까지 폐쇄수면무호흡을 의심해 PSG를 시행한 성인 여성 환자들을 대상으로 했다. 자료수집을 위해 부산백병원 윤리심의위원회의 승인을 받았고(IRB No. 202012-046), 후향적 의무기록 조사연구로 동의 수집은 면 제됐다.

\section{연구 대상}

코골이와 무호흡을 주소로 폐쇄수면무호흡이 의심되어 $\mathrm{PSG}$ 를 시행한 18 세 이상의 한국인 성인남성을 제외한 여자 133 명을 대상으로 했다. 1) PSG에서 AHI가 시간당 5회 미 만, 2) 수면잠복기(sleep latency)가 90분 이상, 3) 중추성 폐 쇄수면무호흡(central apnea $\geq 5 / \mathrm{h}$ ), 4) 파일 손상으로 PSG 원본을 확인할 수 없는 경우는 분석대상에서 제외하였다.

\section{연구 도구}

야간 수면다원검사(Full-night polysomnography, FN-PSG)

PSG는 Remlogic(Embla Systems, Denver, CO, USA)으로 시행했다. 수면 단계와 각성의 판정은 뇌파(C3-A2, C4-A1, F3-A2, F4-A1, O3-A2, O2-A1), 안전위도(electrooculography), 턱 근전도(chin electromyography)로 했다. 온도감 지센서와 압력센서로 호흡량을 측정하였고, 흥곽과 복부벨 트를 이용하여 호흡운동을 측정했다. 그 외 맥박산소측정 (pulse oximetry), 심전도, 양쪽 앞정강근(tibialis anterior muscle)의 근전도와 체위를 측정했고, 검사 전 과정은 비디 오로 기록했다. PSG 당일에는 수면에 영향을 미치는 알코올 이나 카페인이 함유된 음료를 복용하지 않도록 했다.
수면 단계, 호흡사건 및 각성 등에 대한 판독은 미국 수면 학회의 지침에 따랐다. ${ }^{14}$ 무호흡(apnea)은 10 초 이상 호흡이 멈추거나, 비강의 온도와 압력센서를 통해 공기흐름이 $90 \%$ 이상 감소하는 경우, 저호흡(hypopnea)은 10초 이상 공기흐 름이 $30 \%$ 이상 감소와 산소포화도가 $3 \%$ 이상 떨어지거나 각성을 보일 때로 하였다. ${ }^{14}$ 폐쇄수면무호흡은 AHI가 $5 / \mathrm{h}$ 이상인 경우로 정의했다.

\section{설문지}

설문지는 수면 클리닉에 처음 방문한 날 작성되었다.

엡워스졸음척도(Epworth Sleepiness Scale)

주관적인 주간 졸림증(daytime sleepiness)의 정도를 나타 내는 척도로, 8가지 상황에서 잠이 들 수 있는 가능성을 0 (절 대 졸지 않음)에서 3(졸 것 같음) 범위로 평가한다. 총점 0 24점이다. 점수가 클 수록 졸림증이 심하고, 10점 이상이면 과도한 주간졸림(excessive daytime sleepiness)이 있음을 의 미한다. ${ }^{15}$

벡 우울 척도(Beck Depression Inventory-II)

지난 2주간 우울함의 정도를 측정하는 것으로 21 가지 항 목으로 구성된다. 총점은 0 63점이며, 점수가 클 수록 우울 함을 뜻한다. 한국인을 대상으로 임상적으로 의미있는 우울 증상의 총점 절단값(cutoff value)은 17점이다. ${ }^{16}$

\section{자료 분석}

$\mathrm{FN}-\mathrm{PSG}$ 의 $\mathrm{AHI}$ 를 기준값으로 잡고, 검사를 위해 불을 끈 시점을 PSG 검사 시작시간으로 설정하고, 120 분 또는 90 분 경과 시점의 $\mathrm{AHI}(\mathrm{T} 120-\mathrm{AHI}, \mathrm{T} 90-\mathrm{AHI})$ 와 일치도를 보았 다. 일치도의 판정은 일치성 상관계수(concordance correlation coefficient, CCC)와 블랜드-앨트먼 도표(Bland-Altman plot)를 이용하였다. FN-AHI에 대한 T120-AHI과 T90$\mathrm{AHI}$ 의 진단적 민감도 및 특이도를 알아보기 위해 각각 $15 / \mathrm{h}$, $30 / \mathrm{h}, 40 / \mathrm{h}$ 의 절단값에 대하여 receiver operating characteristics(ROC) curve를 확인했다. 연령대별 FN-AHI와 T120$\mathrm{AHI}$ 간의 유의한 차이가 있는지 알아보기 위해 윌콕슨 부호 순위검정(Wilcoxon's signed ranks test)을 이용하였다.

\section{결 과}

연구 대상 133 명 중 11 명이 선정기준에서 탈락하여, 성인 여성 122 명의 결과를 분석하였다. 


\section{일반적 특성 및 수면다원검사 결과}

환자들의 나이, 체질량지수, 목둘레를 포함한 인구학적 성 격과 설문 및 PSG 결과는 Table 1과 같다. 수면잠복기, 렘수 면 잠복기의 평균값은 각각 12.1 분, 120.2 분이었다. 122 명은 폐쇄수면무호흡의 중증도에 따라, 경증 56명, 중등도 42명, 중증 24명으로 분류되었다. 앙와위(supine)와 렘수면시 AHI 가 증가하는 소견을 보였다.

\section{T120-AHI와 FN-AHI의 일치도}

일치성 상관계수를 이용한 T120-AHI와 FN-AHI는 유의 한 수준의 일치도를 보였다(CCC=0.773)(Fig. 1A). 블랜드-

Table 1. Demographic and polysomnographic characteristics of study subjects $(n=122)$

\begin{tabular}{|c|c|}
\hline Variables & Values \\
\hline \multicolumn{2}{|l|}{ Demographic variables } \\
\hline Age (yr) & $57.3 \pm 12.77$ \\
\hline Body mass index $\left(\mathrm{kg} / \mathrm{m}^{2}\right)$ & $25.1 \pm 3.78$ \\
\hline Neck circumference $(\mathrm{cm})$ & $35.0 \pm 2.72$ \\
\hline Current smoking & $6(4.9)$ \\
\hline Alcohol use & $41(33.6)$ \\
\hline Sedatives use in test night & $22(18.0)$ \\
\hline Epworth Sleepiness Scale & $7.7 \pm 5.11$ \\
\hline Beck Depression Inventory & $14.4 \pm 10.05$ \\
\hline \multicolumn{2}{|l|}{ Polysomnographic parameters } \\
\hline Time in bed (min) & $474.9 \pm 46.55$ \\
\hline Total sleep time (min) & $396.7 \pm 64.56$ \\
\hline Sleep latency (min) & $12.1 \pm 12.71$ \\
\hline REM latency (min) & $120.2 \pm 66.33$ \\
\hline Sleep efficiency (\%) & $82.1 \pm 10.15$ \\
\hline REM sleep (\%) & $19.3 \pm 11.39$ \\
\hline \multicolumn{2}{|l|}{ NREM sleep (\%) } \\
\hline N1 sleep & $22.7 \pm 10.41$ \\
\hline N2 sleep & $57.1 \pm 10.97$ \\
\hline N3 sleep & $4.5 \pm 6.46$ \\
\hline $\mathrm{AHI}(/ \mathrm{h})$ & $20.3 \pm 13.40$ \\
\hline REM-AHI (/h) & $29.1 \pm 18.05$ \\
\hline NREM-AHI (/h) & $18.0 \pm 14.47$ \\
\hline Supine AHI (/h) & $28.3 \pm 19.7$ \\
\hline Lowest $\mathrm{SaO}_{2}(\%)$ & $83.0 \pm 6.21$ \\
\hline Arousal Index (/h) & $22.0 \pm 21.61$ \\
\hline $5 / \mathrm{h} \leq \mathrm{AHI}<15 / \mathrm{h}$ & $56(45.9)$ \\
\hline $15 / \mathrm{h} \leq \mathrm{AHI}<30 / \mathrm{h}$ & $42(34.4)$ \\
\hline $30 / \mathrm{h} \leq \mathrm{AHI}$ & $24(19.7)$ \\
\hline
\end{tabular}

Values are presented as mean \pm standard deviation or number (\%). AHI: apnea-hypopnea index
앨트먼 도표에서는, T120-AHI와 FN-AHI 차이값에 대한 평균은 0.46으로 0에 가까운 값을 보였다(Fig. 1B). T120-AHI 에서 $\mathrm{AHI}$ 의 절단값 $15,30,40$ 을 사용한 $\mathrm{ROC}$ 커브 아래의 면적(area under the curve, AUC)은 모두 유의했으며, 각각 의 민감도와 특이도는 절단값 15 일 때 $78.6 \%, 82.7 \%, 30$ 일 때 $79.2 \%, 90.8 \%, 40$ 일 때 $66.7 \%, 96.4 \%$ 였다(Fig. 2).

\section{T90-AHI와 FN-AHI의 일치도}

일치성 상관계수를 이용한 T90-AHI와 FN-AHI에서도 유의한 수준의 일치도를 보였다(CCC=0.739)(Supplementary Fig. 1A in the online-only Data Supplement). 블랜드앨트먼 도표에서는, T90-AHI와 $\mathrm{FN}-\mathrm{AHI}$ 차이값의 평균은 0.02로 0에 가까운 값을 보였다(Supplementary Fig. 1B in the online-only Data Supplement). T90-AHI에서 AHI의 절단값 $15,30,40$ 을 사용한 $\mathrm{AUC}$ 값은 모두 유의했으며, 각 각의 민감도와 특이도는 절단값 15 일 때 $77.1 \%, 86.5 \%, 30$ 일 때 $66.7 \%, 87.8 \%, 40$ 일 때 58.3\%, 93.6\% 였다(Supplementary Fig. 2 in the online-only Data Supplement).

\section{고 찰}

본 연구는 한국 성인 여성 폐쇄수면무호흡 환자에서 분할 수면다원검사의 진단적 의의를 알아보기 위하여, T120-AHI 와 $\mathrm{FN}-\mathrm{AHI}$ 를 비교하였고, T120-AHI의 진단적 유용성을 입증하였다. 이는 이전 연구결과들에서 여성이 남성에 비해 상대적으로 비렘수면 $\mathrm{AHI}$ 가 낮고, 비렘수면 $\mathrm{AHI}$ 와 렘수면 $\mathrm{AHI}$ 의 차이가 심하여, ${ }^{11-13}$ 남성에 비해 분할수면다원검사의 진단적 정확도가 떨어질 것이라는 예상과는 다른 결과였다. Won 등은 2057명의 데이터를 사용한 후향적 연구에서, 폐 쇄수면무호흡 환자의 성별에 따라 PSG 결과를 비교했을 때, 전체 $\mathrm{AHI}$ 값은 남성에서 높고, 특히 비렘수면 $\mathrm{AHI}$ 값의 차 이가 심하나, 렘수면 AHI는 유의한 차이를 보이지 않는다고 하였다. ${ }^{12}$ Zhang 등은 남성보다 여성에서 상대적으로 렘수면 $\mathrm{AHI}$ 가 높고, 마찬가지로 비렘수면 $\mathrm{AHI}$ 는 낮은 결과를 보고 하였다..$^{13}$ 또한 두 연구 모두에서 남성보다 여성의 렘수면 잠 복기가 길었다. ${ }^{12,13}$ 비슷한 체질량지수의 남성이 여성보다 폐 쇄수면무호흡의 정도가 심하고, 남성에서 폐쇄수면무호흡의 유병률이 높은 원인은 아직 명확히 밝혀지지 않았으나, 지방 의 분포, 상기도의 해부학적 구조, 호흡 조절, 호르몬, 노화 등의 여러가지 측면에서 차이가 있기 때문이라고 여겨지고 있다. ${ }^{17}$ 상기도의 구조에서, 남성에서 더 길고 늘어진(floppy) 구인두를 가지고, 더 크고 지방이 많은 혀를 가지고 있으며, ${ }^{17}$ 나이가 들면서, 여성에 비해 남성에서 턱끝혀근의 음압에 대 


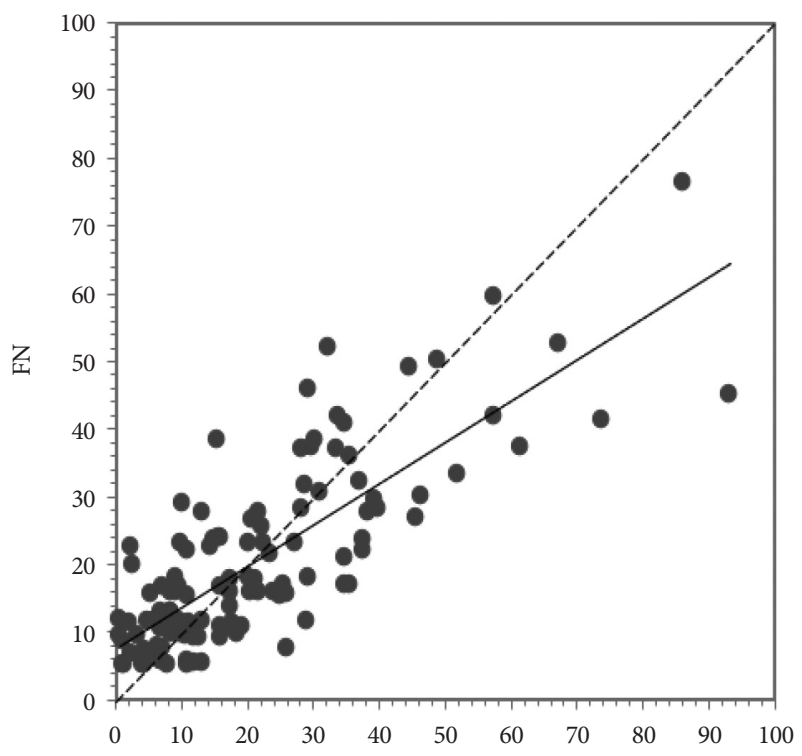

A T120

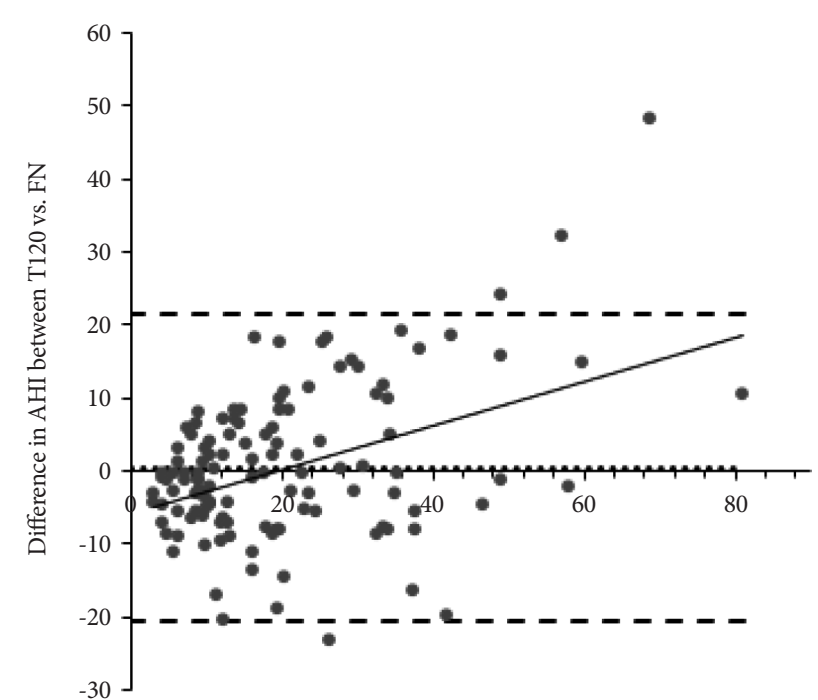

Mean of AHI in T120 and FN

Figure 1. Agreement between AHI derived from T120 and FN. (A) Scatter plot of the AHI derived from T120 and FN. The concordance correlation coefficient for these data was 0.773 , indicating a moderate degree of correlation. The dashed line is the $y=x$ line, and the solid line is the trend line. (B) Bland-Altman plot for the AHI derived from T120 and FN. The dotted line indicates the mean of the differences or bias, and the dashed lines indicate the lower and upper $95 \%$ limits of agreement. AHI: apnea-hypopnea index.
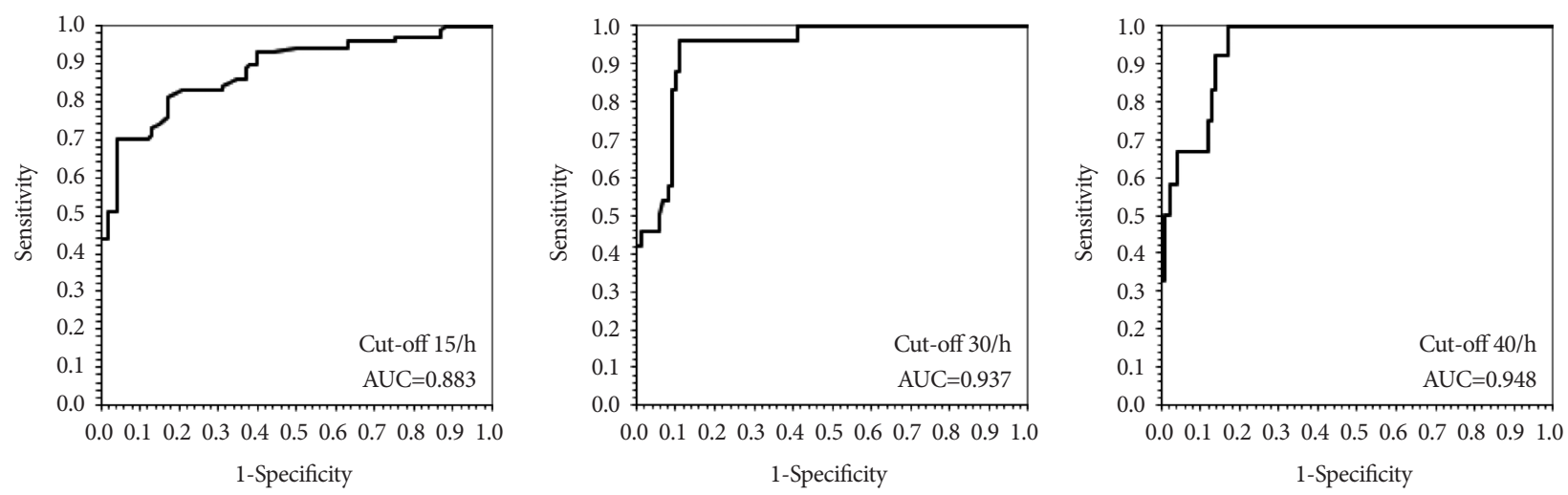

Figure 2. Receiver operating characteristic curves and the area under the curves according to each cut-off point for the apnea-hypopnea index in T120. AUC: area under the curve.

한 반응이 떨어지면서, 기도가 폐쇄되기 쉽다. ${ }^{18}$ 또한 비렘수 면에서 상기도 저항이 증가하였을 때, 자발적 각성 이후 여 성에 비해 저환기되고 기도 폐쇄성(collapsibility)이 증가하 는 등의 각성 이후 발생하는 상기도의 불안정성으로도 일부 설명하고 있다..$^{12,19-21}$ 성호르몬의 역할도 주요하게 여겨지는 데, 폐경 이전에 비해 폐경기 및 폐경기 이후 AHI가 급격히 높아지고, 폐경기 이후의 여성에서 폐쇄수면무호흡의 유병 률이 높다. $22-24$ 이러한 폐경기 전후로의 급격한 변화는 에스 트로겐과 프로게스테론이 환기를 자극하고 상기도를 확장 하는 작용을 하여, 폐쇄수면무호흡에 저항적인 작용을 할 것 이라는 연구결과들이 있으나, 그 기전이 아직 명확히 밝혀지 지는 않았다. 24,25 한 연구에서는, 폐경 이후 여성에서 호르몬 치료를 시행하지 않을 시 시행하는 군보다 폐쇄수면무호흡
의 위험도가 4 배 이상 증가한다고 발표했다. ${ }^{26}$ 또한 수술 후 발생한 폐경에서, 에스트로겐/프로게스테론 복합 호르몬 치 료를 시행한 후 AHI가 감소했다는 연구결과도 있었다.22 폐 경 이후 호르몬의 변화로, 여성에서 몸통의 지방이 증가하 여, 남성의 지방분포와 같이 변화하는 것 또한 폐쇄수면무호 흡의 주요 위험인자로 밝혀지고 있다. ${ }^{27,28}$

본 연구에서도, 렘수면 $\mathrm{AHI}$ 가 비렘수면 $\mathrm{AHI}$ 보다 높았고 평균 렘수면 잠복기는 120.2 분, T120에 렘수면이 있었던 환 자가 60명, 그 중 앙와위 렘수면이 포함된 경우는 45명이었 으나, T120-AHI가 FN-AHI와 높은 일치도를 보였다(Supplementary Table 1 in the online-only Data Supplement). 본 연구대상의 평균 연령이 57세로 높고, 대부분 폐경기 이 후의 여성임을 고려하면, 연령에 의해 남녀의 $\mathrm{AHI}$ 차이가 

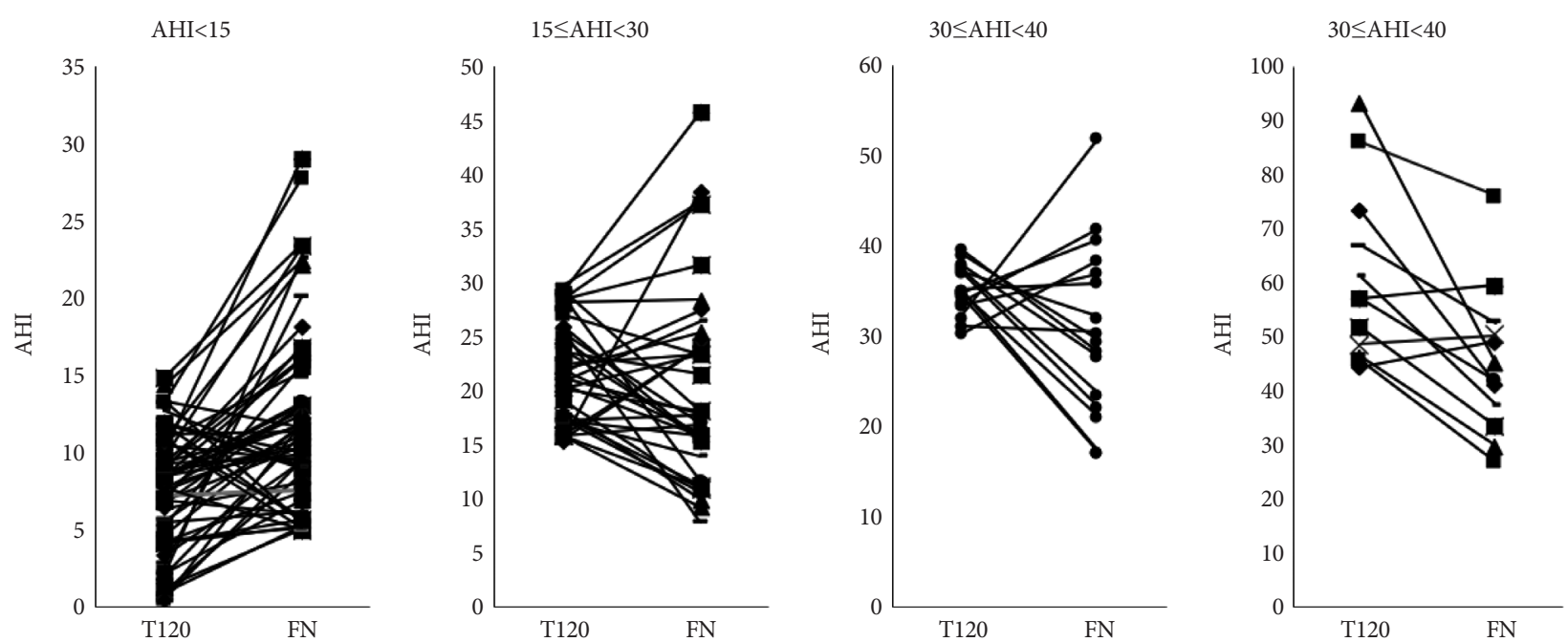

Figure 3. Distribution of the AHI between $\mathrm{T} 120$ and $\mathrm{FN}$ in four subgroups according to the $\mathrm{AHI}$ in $\mathrm{T} 120$. AHI: apnea-hypopnea index.

희석되었을 가능성도 고려할 수 있다(Supplementary Table

2 in the online-only Data Supplement).

처음 2시간 혹은 3시간의 동안의 $\mathrm{AHI}$ 와, 수면다원검사의 $\mathrm{AHI}$ 간의 높은 일치도를 통해 분할수면다원검사의 진단적 정확도가 높은 것은 이미 알려져 있으나, 주로 서양인들을 대상으로 한 연구결과였다. ${ }^{6-9} \mathrm{Kim}$ 등은 한국인 남자 123 명 을 포함한 한국인 150 명의 데이터를 분석한 결과, 처음 두시 간 동안의 $\mathrm{AHI}$ 와, 수면다원검사의 $\mathrm{AHI}$ 가 유의한 차이가 없 었다. ${ }^{10}$ 본 연구를 통해, 여성을 포함한 한국인 폐쇄수면무호 흡 환자에 대한 분할수면다원검사의 진단적 의의가 더욱 명 확해질 것이라 생각한다.

또한, T120에서 AHI $15,30,40$ 의 절단값을 사용하였을 때, 절단값이 높아질수록 민감도가 감소하였고, 특히 절단값 40 일 때 $66.7 \%$ 의 낮은 민감도를 나타내, 중등도 이상의 폐쇄수 면무호흡에서 분할수면다원검사를 권고하는 최근의 권고 사항을 지지할 수 있는 결과이다.

본 연구에서는, 이전 연구들에서 많이 사용하지 않은, 처음 90분 동안의 $\mathrm{AHI}$ 의 진단적 유용성을 함께 검토하였으며, 흥 미롭게도 T90-AHI도 T120-AHI와 유의한 차이가 없었으 며, FN-AHI와 높은 일치도를 보였다. 두 시간 미만의 진단 적 수면다원검사를 통한 분할수면다원검사에 대한 연구는 아직 미미하나, 이후에도 이러한 결과들이 반복된다면, 추후 분할수면다원검사의 진단적 수면검사에 사용하는 시간을 줄 이고, 양압 적정에 배분하는 시간을 늘려 양압 적정의 성공 률을 높이는데 보탬이 될 수도 있을 것이다.

본 연구는 단일 상급종합병원 수면센터에서 $\mathrm{PSG}$ 를 시행 한 성인 여성 환자만을 대상으로 한 후향적 연구이며, 모든 환자들의 폐경 여부를 명확히 확인하지 못하였고, 검사를 시 행한 연령대 또한 높아, 대부분의 환자가 폐경기 혹은 폐경
기 이후의 연령대에 해당하여 여성 폐쇄수면무호흡 환자 전 체를 대표하지 못한다(Supplementary Table 2 in the online-only Data Supplement).

또한 성인 남성 및 정상 대조군의 데이터가 없어 비교할 수 없으며, T120에서 $\mathrm{AHI}$ 를 제외한 수면다원검사 결과를 함께 제시하지 않아, T120과 FN의 AHI 일치도를 보려는 목적에는 부합하나, 폭넓은 정보를 제공하지 못한 아쉬운 점이 있다.

본 연구를 통해, 폐쇄수면무호흡이 의심되는 성인 여성을 대상으로 한 분할수면다원검사의 진단적 의의를 확인할 수 있었다. 앞으로 여성 폐쇄수면무호흡 환자에서 분할수면다 원검사의 유용성을 정립하기 위해, 그리고 두시간 이내의 분 할수면다원검사의 진단 도구로서의 효용성에 대한 더 많은 연구들이 필요할 것이다.

\section{Supplementary Materials}

The online-only Data Supplement is available with this article at https:// doi.org/10.13078/jsm.200027.

\section{Acknowledgments}

None.

\section{Conflicts of Interest}

The authors have no potential conflicts of interest to disclose.

\section{ORCID iDs}

Mi-Ri Kang

Ki-Hwan Ji

https://orcid.org/0000-0002-9833-023X

https://orcid.org/0000-0002-5371-5398

\section{Author Contributions}

Conceptualization: Ki-Hwan Ji. Data curation: Mi-Ri Kang. Formal analysis: Mi-Ri Kang. Investigation: Mi-Ri Kang. Methodology: Mi-Ri Kang, Ki-Hwan Ji. Writing_original draft: Mi-Ri Kang, Ki-Hwan Ji. Writing_review \& editing: Mi-Ri Kang, Ki-Hwan Ji. 


\section{REFERENCES}

1. Young T, Palta M, Dempsey J, Skatrud J, Weber S, Badr S. The occurrence of sleep-disordered breathing among middle-aged adults. N Engl J Med 1993;328:1230-1235. https://doi.org/10.1056/NEJM199304293281704.

2. Shahar E, Whitney CW, Redline S, et al. Sleep-disordered breathing and cardiovascular disease: cross-sectional results of the Sleep Heart Health Study. Am J Respir Crit Care Med 2001;163:19-25. https://doi. org/10.1164/ajrccm.163.1.2001008.

3. BaHammam AS, ALAnbay E, Alrajhi N, Olaish AH. The success rate of split-night polysomnography and its impact on continuous positive airway pressure compliance. Ann Thorac Med 2015;10:274-278. https:// doi.org/10.4103/1817-1737.160359.

4. Kushida CA, Littner MR, Morgenthaler T, et al. Practice parameters for the indications for polysomnography and related procedures: an update for 2005. Sleep 2005;28:499-521. https://doi.org/10.1093/sleep/28.4.499.

5. Kapur VK, Auckley DH, Chowdhuri S, et al. Clinical practice guideline for diagnostic testing for adult obstructive sleep apnea: an American Academy of Sleep Medicine clinical practice guideline. J Clin Sleep Med 2017;13:479-504. https://doi.org/10.5664/jcsm.6506.

6. Khawaja IS, Olson EJ, van der Walt C, et al. Diagnostic accuracy of split-night polysomnograms. J Clin Sleep Med 2010;6:357-362. https:// doi.org/10.5664/jcsm. 27877 .

7. McArdle N, Grove A, Devereux G, Mackay-Brown L, Mackay T, Douglas NJ. Split-night versus full-night studies for sleep apnoea/hypopnoea syndrome. Eur Respir J 2000;15:670-675. https://doi.org/10.1034/j.13993003.2000.15d08.x.

8. Rodway GW, Sanders MH. The efficacy of split-night sleep studies. Sleep Med Rev 2003;7:391-401. https://doi.org/10.1053/smrv.2002.0272.

9. Strollo PJ Jr, Sanders MH, Costantino JP, Walsh SK, Stiller RA, Atwood CW Jr. Split-night studies for the diagnosis and treatment of sleep-disordered breathing. Sleep 1996;19:S255-S259. https://doi.org/10.1093/ sleep/19.suppl_10.s255.

10. Kim DK, Choi J, Kim KR, Hwang KG, Ryu S, Cho SH. Rethinking AASM guideline for split-night polysomnography in Asian patients with obstructive sleep apnea. Sleep Breath 2015;19:1273-1277. https:// doi.org/10.1007/s11325-015-1158-2.

11. Subramanian S, Hesselbacher S, Mattewal A, Surani S. Gender and age influence the effects of slow-wave sleep on respiration in patients with obstructive sleep apnea. Sleep Breath 2013;17:51-56. https://doi.org/ 10.1007/s11325-011-0644-4.

12. Won CHJ, Reid M, Sofer T, et al. Sex differences in obstructive sleep apnea phenotypes, the multi-ethnic study of atherosclerosis. Sleep 2020;43:zsz274. https://doi.org/10.1093/sleep/zsz274.

13. Zhang Z, Cheng J, Yang W, Zou H, Su C, Miao J. Gender differences in clinical manifestations and polysomnographic findings in Chinese patients with obstructive sleep apnea. Sleep Breath 2020;24:1019-1026. https://doi.org/10.1007/s11325-019-01943-y.

14. Berry RB, Brooks R, Gamaldo CE, et al. The AASM manual for the scoring of sleep and associated events. Rules, Terminology and Technical Specifications, Darien, Illinois, American Academy of Sleep Medicine, 2012;176.
15. Johns MW. A new method for measuring daytime sleepiness: the Epworth sleepiness scale. Sleep 1991;14:540-545. https://doi.org/10.1093/ sleep/14.6.540.

16. Park K, Jaekal E, Yoon S, Lee SH, Choi KH. Diagnostic utility and psychometric properties of the Beck Depression Inventory-II among Korean adults. Front Psychol 2020;10:2934. https://doi.org/10.3389/ fpsyg.2019.02934.

17. Lin CM, Davidson TM, Ancoli-Israel S. Gender differences in obstructive sleep apnea and treatment implications. Sleep Med Rev 2008; 12:481-496. https://doi.org/10.1016/j.smrv.2007.11.003.

18. Malhotra A, Huang Y, Fogel R, et al. Aging influences on pharyngeal anatomy and physiology: the predisposition to pharyngeal collapse. Am J Med 2006;119:72.e9-72.e14. https://doi.org/10.1016/j.amjmed. 2005.01.077.

19. Jordan AS, Eckert DJ, Catcheside PG, McEvoy RD. Ventilatory response to brief arousal from non-rapid eye movement sleep is greater in men than in women. Am J Respir Crit Care Med 2003;168:15121519. https://doi.org/10.1164/rccm.200302-150OC.

20. Jordan AS, Wellman A, Edwards JK, et al. Respiratory control stability and upper airway collapsibility in men and women with obstructive sleep apnea. J Appl Physiol (1985) 2005;99:2020-2027. https://doi. org/10.1152/japplphysiol.00410.2004.

21. Jordan AS, McEvoy RD, Edwards JK, et al. The influence of gender and upper airway resistance on the ventilatory response to arousal in obstructive sleep apnoea in humans. J Physiol 2004;558:993-1004. https://doi.org/10.1113/jphysiol.2004.064238.

22. Pickett CK, Regensteiner JG, Woodard WD, Hagerman DD, Weil JV, Moore LG. Progestin and estrogen reduce sleep-disordered breathing in postmenopausal women. J Appl Physiol (1985) 1989;66:1656-1661. https://doi.org/10.1152/jappl.1989.66.4.1656.

23. Mirer AG, Young T, Palta M, Benca RM, Rasmuson A, Peppard PE. Sleep-disordered breathing and the menopausal transition among participants in the Sleep in Midlife Women Study. Menopause 2017;24: 157-162. https://doi.org/10.1097/GME.0000000000000744.

24. Popovic RM, White DP. Upper airway muscle activity in normal women: influence of hormonal status. J Appl Physiol (1985) 1998;84:10551062. https://doi.org/10.1152/jappl.1998.84.3.1055.

25. Pillar G, Malhotra A, Fogel R, Beauregard J, Schnall R, White DP. Airway mechanics and ventilation in response to resistive loading during sleep: influence of gender. Am J Respir Crit Care Med 2000;162:16271632. https://doi.org/10.1164/ajrccm.162.5.2003131.

26. Bixler EO, Vgontzas AN, Lin HM, et al. Prevalence of sleep-disordered breathing in women: effects of gender. Am J Respir Crit Care Med 2001;163:608-613. https://doi.org/10.1164/ajrccm.163.3.9911064.

27. Trémollieres FA, Pouilles JM, Ribot CA. Relative influence of age and menopause on total and regional body composition changes in postmenopausal women. Am J Obstet Gynecol 1996;175:1594-1600. https:// doi.org/10.1016/s0002-9378(96)70111-4.

28. Toth MJ, Tchernof A, Sites CK, Poehlman ET. Effect of menopausal status on body composition and abdominal fat distribution. Int J Obes Relat Metab Disord 2000;24:226-231. https://doi.org/10.1038/sj.ijo.0801118. 


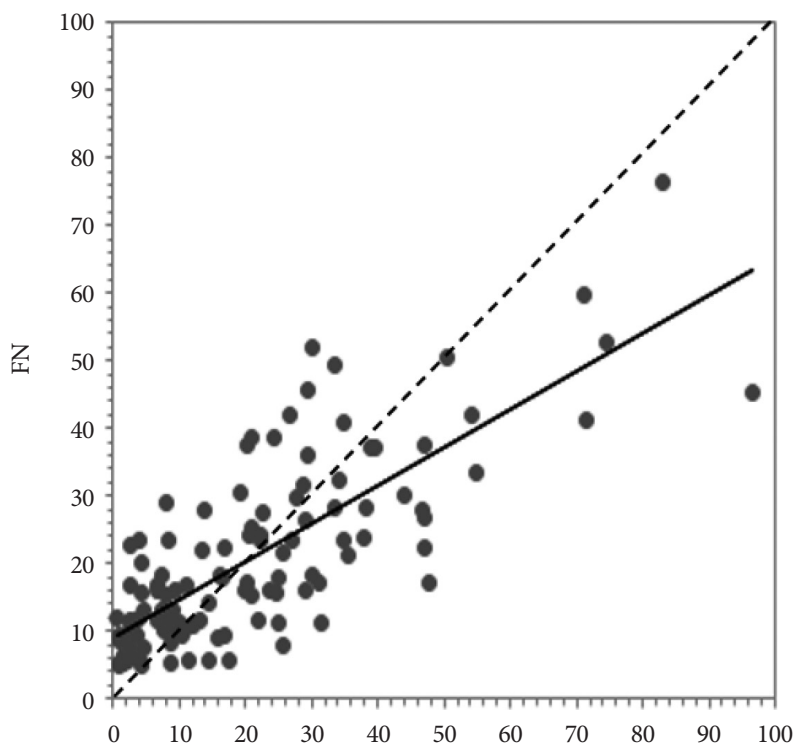

A

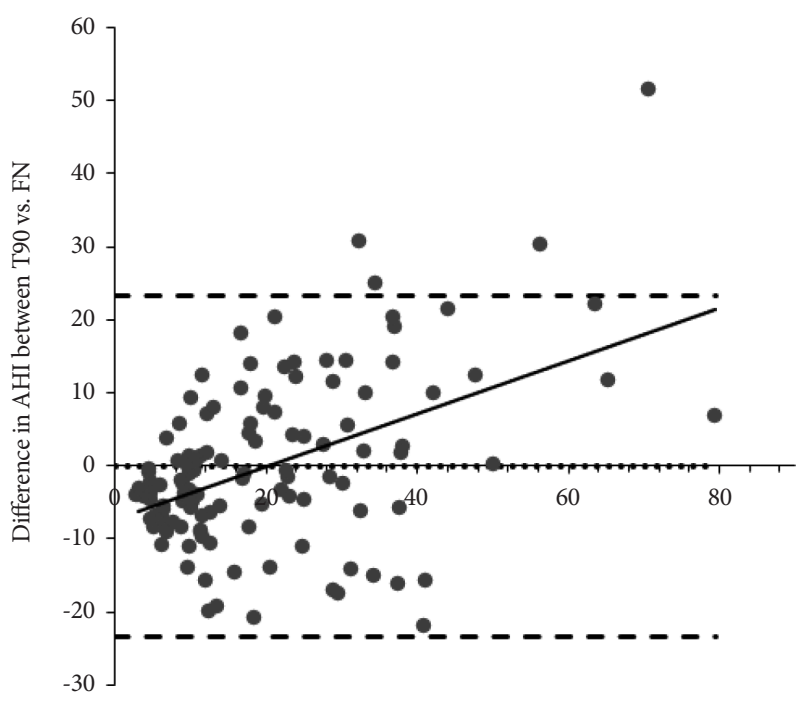

B

Mean of AHI in T90 and FN

Supplementary Figure 1. Agreement between AHI derived from T90 and FN. (A) Scatter plot of the AHI derived from T90 and FN. The concordance correlation coefficient for these data was 0.739 , indicating a moderate degree of correlation. The dashed line is the $y=x$ line, and the solid line is the trend line. (B) Bland-Altman plot for the AHI derived from T90 and FN. The dotted line indicates the mean of the differences or bias, and the dashed lines indicate the lower and upper $95 \%$ limits of agreement. AHI: apnea-hypopnea index. 

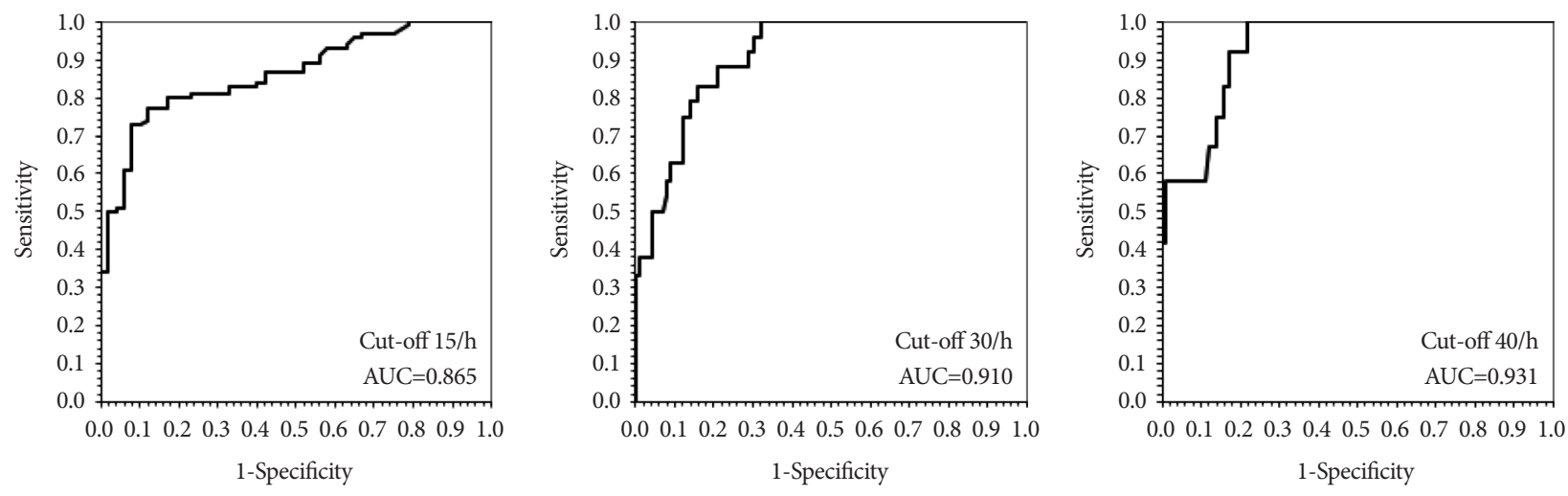

Supplementary Figure 2. Receiver operating characteristic curves and the AUC according to each cut-off point for the apnea-hypopnea index in T90. AUC: area under the curve. 
Supplementary Table 1. Polysomnographic characteristics of subjects with REM sleep in T120 $(n=60)$

\begin{tabular}{lc}
\hline \multicolumn{1}{c}{ Variables } & Values \\
\hline Total sleep time (min) & $98.2 \pm 17.45$ \\
REM sleep (\%) & $15.2 \pm 11.69$ \\
Patients with supine REM sleep & $45(75)$ \\
Supine REM sleep (\%) & $13.1 \pm 9.86$ \\
AHI (/h) & $18.3 \pm 12.63$ \\
REM-AHI (/h) & $35.7 \pm 24.90$
\end{tabular}

Values are presented as mean \pm standard deviation or number (\%). AHI: apnea-hypopnea index 
Supplementary Table 2. The mean values of T120-AHI and FN$\mathrm{AHI}$ according to age group

\begin{tabular}{ccccc}
\hline Age $(\mathrm{yr})$ & $\mathrm{n}(\%)$ & T120-AHI & FN-AHI & $p$ \\
\hline $18-39$ & $10(8.2)$ & $18.5 \pm 11.52$ & $18.8 \pm 11.59$ & 0.515 \\
$40-49$ & $14(11.5)$ & $18.4 \pm 18.17$ & $15.2 \pm 10.19$ & 0.753 \\
$50-59$ & $41(33.6)$ & $19.2 \pm 18.63$ & $18.5 \pm 12.52$ & 0.722 \\
$60-89$ & $57(46.7)$ & $22.8 \pm 17.74$ & $23.0 \pm 22.78$ & 0.794 \\
\hline
\end{tabular}

Values are presented as mean \pm standard deviation or number (\%). $p$ value for T120-AHI vs. FN-AHI. AHI: apnea-hypopnea index 